ks. Andrzej Proniewski

Uniwersytet $w$ Bialymstoku

0000-0003-0382-3646

DOI: 10.15290/std.2020.06.07

\title{
DUCH ŚWIĘTY W MAGISTERIUM PAPIEŻY PRZEŁOMU XIX/XX WIEKU
}

\section{THE HOLY SPIRIT IN THE TEACHING OF THE POPES AT THE TURN OF THE 19-TH - 20-TH CENTURY}

Popes wrote about the Holy Spirit at various times in the history of the Church, also at the turn of the 19th and 20th centuries.

The reflections bring us closer to the teaching on the Holy Spirit by Leo XIII (1810-1903), St. Pius X (1835-1914), Benedict XV (1854-1922). These popes ushered in a "new era" of the Holy Spirit. Their successors: Pius XI (1857-1939), Pius XII (1876-1958), St. John XXIII (1881-1963) were described as heralds of a "new Pentecost". Such a formula is extremely interesting, if only because of at least two a priori assumptions, namely that something like a "new Pentecost" does exist and that the popes mentioned were its heralds two a priori assumptions, namely that something like a "new Pentecost" does exist and that the popes mentioned were its, whatever it was, heralds.

This study focused only on some of the aforementioned aspects.

Key words: Holy Spirit, new Pentecost, Popes teaching.

\section{Wstęp}

Duch Święty jako Trzecia Osoba Trójcy Świętej prowadzi Kościół ku urzeczywistnianiu Zbawienia. Kościół napełniony Duchem Świętym prosperuje jako dynamiczna wspólnota, dzięki współpracy ludzi z łaską Bożą. Duch Święty, który oddziałuje na Kościół przyczynia się do tego, aby prawdy objawione przez 
Boga znajdowały w nim swoją żywotność i skuteczność. Sprzyja temu działaniu pogłębiona refleksja pneumatologiczna teologów i apostolska posługa papieży, ich kanoniczna ortodoksyjność, ewangelizacyjno-misyjna aktywność, posługa miłosierdzia i działania prowadzące ku prawdzie i sprawiedliwości.

Ojcowie Kościoła oraz teologowie kolejnych wieków i epok wypowiadali się o Duchu Świętym. Mówili i pisali o Duchu Świętym także papieże w różnym okresie dziejów Kościoła również przełomu XIX i XX wieku. Refleksje zawarte w niniejszym artykule przybliżają nauczanie o Duchu Świętym: Leona XIII (1810-1903), św. Piusa X (1835-1914), Benedykta XV (1854-1922). Wymienieni papieże zapoczątkowali „nową erę” Ducha Świętego. Kolejni: Pius XI (1857-1939), Pius XII (1876-1958), św. Jan XXIII (1881-1963) zostali określeni jako zwiastunowie „nowej Pięćdziesiątnicy”. Taka formuła jest niezwykle interesująca chociażby z tego względu, że zawiera przynajmniej dwa założenia aprioryczne, a mianowicie, że coś takiego jak „nowa Pięćdziesiątnica” rzeczywiście istnieje oraz, że wymienieni papieże rzeczywiście byli jej, czymkolwiek by nie była, zwiastunami. Materiał zawarty w podjętym studium uwzględni tylko niektóre aspekty podjętych zagadnień.

\section{„Nowa era” Ducha Świętego}

Leon XIII, którego pontyfikat trwał od 1878 do 1903 roku, znany jest przede wszystkim ze społecznej encykliki Rerum novarum (1891), która stanowi po dziś dzień podwaliny katolickiej nauki społecznej. Leona XIII możemy z całą pewnością określić jako tego, który rozpoczął „nową erę” Ducha Świętego. Odznaczał się on powrotem do zaniedbanej przez poprzednie stulecia refleksji na temat Trzeciej Osoby Trójcy Świętej. Wydał dwie encykliki dotyczące bezpośrednio Ducha Świętego: Provida Matris Caritate (1895), ustanawiająca nowennę przed uroczystością Zesłania Ducha Świętego oraz Divinum illud munus (1897) o Duchu Świętym. Dokumenty te miały powstać pod wpływem bł. Eleny Guerry (1835-1914), założycielki Sióstr Ducha Świętego. Niedługo przed śmiercią, Leon XIII wraz z Kościołem wszedł w XX wiek, intonując w Bazylice Świętego Piotra uroczyste i błagalne zarazem Veni Creator Spiritus ${ }^{1}$.

Leon XIII encyklikę Divinum illud munus rozpoczął ewangelizacyjnym akcentem, zapraszającym z pomocą Ducha Świętego, wszystkich ludzi dobrej woli na łono Kościoła: „Boski ten obowiązek, który dla dobra rodzaju ludzkiego Jezus Chrystus przyjął najświęciej od Ojca, ma ostatecznie to na względzie, by ludzie stali się uczestnikami szczęśliwego życia w wiecznej chwale, zaś w konkretnych warunkach biegu czasu mieli w sobie i tak pielęgnowali życie łaski rozkwitające

$1 \quad$ Por. S. Szostakiewicz, Duch Święty a duch naszych czasów, https://opoka.org.pl/biblioteka/T/TS/czasy.html [01.03.2021]. 
wreszcie do życia niebieskiego. Dlatego sam Zbawiciel nie przestaje zapraszać z największą dobrocią wszystkich ludzi bez wyjątku, bez różnicy narodowości i języka - na łono swego Kościoła”2.

W dalszej części opisał zapowiedź przyjścia Pocieszyciela, odwołując się do Ewangelii wedtug św. Jana: „Pożyteczne jest dla was moje odejście: jeśli bowiem nie odejdę, Pocieszyciel nie przybędzie do was, jeżeli zaś odejdę, poślę go do was" (J 16, 7). Papież wskazał na rolę Ducha Świętego jako orędownika, pocieszyciela i nauczyciela.

Leon XIII odwołał się do osobistego doświadczenia i opisał, w jaki sposób starał się kierować natchnieniami Ducha Świętego w czasie swojego pontyfikatu. Pierwszą kwestią, wymagającą szczególnej asystencji Ducha Świętego była praca nad ustanowieniem zasad życia chrześcijańskiego w społeczeństwie. Druga dotyczyła pojednania z odłączonymi od Kościoła katolickiego. Te dwa punkty Papież w sposób szczególny zawierzył Duchowi Świętemu. Do podobnego zachowania podyktowanego potrzebą działania w Duchu Świętym zachęcał wszystkich wiernych katolików: „Gorąco pragniemy, by w duchu każdego człowieka pogłębiała się wiara w tajemnicę Przenajświętszej Trójcy a szczególna pobożność wzrastała do Ducha Bożego, od którego - muszą to przyznać - otrzymali najwięcej ci, którzy kroczą drogą prawdy i sprawiedliwości”’3.

Papież podkreślił nieskończoną moc Ducha Świętego. Następnie poświęcił dużo uwagi działaniu Ducha Świętego w Kościele. Wskazał, że Kościół jest dziełem Bożym, o czym świadczą liczne obecne w nim charyzmaty. „Wystarczy stwierdzić, że ponieważ Chrystus jest głową Kościoła, Duch Święty jest jego duszą. Tym, czym dusza jest w naszym ciele, tym Duch Święty jest w ciele Chrystusa, którym jest Kościól"4.

W końcowej części encykliki Leon XIII ukazał działanie Ducha Świętego w człowieku, w duszy ludzkiej, z uwzględnieniem szczególnego znaczenia sakramentów: chrztu i bierzmowania. Opisał także pokrótce dary Ducha Świętego, jako prowadzące ducha do szczytu świętości i doskonałości ${ }^{5}$. Następnie zachęcił chrześcijan do uległości poruszeniom Ducha Świętego oraz do uczynienia z siebie świątyni Ducha.

Kończąc dokument Leon XIII zachęcił wszystkich do jeszcze większego kultu Ducha Świętego oraz nałożył odpust zupełny za odmówienie ustanowionej dwa lata wcześniej nowenny przed uroczystością Zesłania Ducha Świętego.

2 Leon XIII, Divinum Illud, http://rodzinakatolicka.pl/leon-xiii-divinum-illud-o-duchu-swietym/ [01.03.2021].

3 Tamże.

4 Tamże.

5 Tamże. 
Następcą Leona XIII na Stolicy Piotrowej został Pius X, jak się później okazało pierwszy Papież włączony w poczet świętych od św. Piusa V. Wprawdzie Pius X nie napisał dzieła poświęconego w całości Duchowi Świętemu, jednak odwołania pneumatologiczne można odnaleźć w wielu jego tekstach.

Niedługo po rozpoczęciu pontyfikatu Pius X napisał encyklikę E supremi apostolatus (1903). Można ją nazwać swoistą encykliką programową, kierującą Kościół na tory typowo piusowej zasady wynikającej z jego motta „Omnia in-

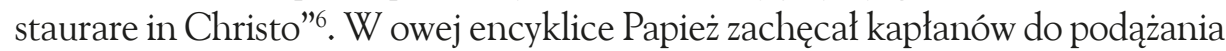
za Duchem Świętym: „Nie brak bowiem kapłanów, którzy, idąc za pociąiem upodobań własnych, zużywają swą dzielność na sprawy raczej powierzchowne, niż głębszej użyteczności: a znów niewielu jest takich, którzy by, za przykładem Chrystusowym, stosowali do siebie owe słowa Proroka: Duch Pański spoczywa na Mnie, ponieważ Mnie namaścił i posłał Mnie"?.

W tej samej encyklice Pius X inspirował kapłanów do współpracy z wiernymi świeckimi, wskazując jednakowoż na właściwe respektowanie zarządzeń hierarchii: „Zatem nie tylko kapłani, ale i wszyscy bez wyjątku wierni mają współpracować w sprawie Bożej i dusz ludzkich: rozumie się, nie na własną rękę i nie we własnym kierunku, lecz zawsze pod kierownictwem i przewodnictwem biskupów; albowiem przewodzić, nauczać i kierować w Kościele nie dano nikomu poza wami, «których Duch Święty ustanowił, abyście rządzili Kościołem Bożym» (Dz 20, 28)" ". Papież przypomniał o tym, że biskupi są tymi, przez których działa Duch Święty.

Warto wspomnieć także o encyklice Pascendi Dominici gregis (1907), w której Pius X niejako porównuje na zasadzie przeciwstawienia zasady Kościoła, prowadzonego przez Ducha Świętego z zasadami modernistów, prowadzonych przez innego Ducha. W tej encyklice po przytoczeniu błędów polegających na empirycznym i uczuciowym odczytywaniu Pisma Świętego Papież przypomniał prawdę odwieczną: „My zaś, Czcigodni Bracia, dla których jedną i jedyną prawdą jest prawda zawarta w księgach świętych, które powstały pod natchnieniem Ducha Świętego, a których autorem jest Bóg - twierdzimy, że powyższe zdania są równoznaczne z przypisywaniem samemu Bogu kłamstwa, kłamstwa oficjalnego gwoli korzyści”".

$6 \quad$ Odnowić wszystko w Chrystusie.

7 Pius X, E supremiapostolatus, http://rodzinakatolicka.pl/sw-pius-x-e-supremi-apostolatuso-odnowieniu-wszystkiego-w-chrystusie/ [01.03.2021].

8 Tamże.

9 Pius X, Pascendi Dominici gregis, http://rodzinakatolicka.pl/sw-pius-x-pascendi-dominicigregis-o-zasadach-modernistow/ [01.03.2021]. 
Święty Pius X w podsumowaniu encykliki wskazał wyraźnie na ogromne niebezpieczeństwo rozwoju wiary czysto uczuciowej, ukierunkowanej na rzekome poruszenia ducha, odczuwane empirycznie przez wiernych: „Z pracy nad duszami znacie dobrze te, które zwykły iść za popędem uczucia; wiecie to również $z$ dzieł ascetycznych, którymi tak pogardzają moderniści, a przecież owe dzieła ascetyczne wykazują zasoby wiedzy o wiele wyższej, niż ich wiedza oraz wyższą od nich subtelność obserwacji; to też wydaje nam się szaleństwem a przynajmniej wielką nieroztropnością podążać bez żadnego badania za tymi wewnętrznymi doświadczeniami, które tak wielką rolę odgrywają u modernistów"10.

Warto zwrócić także uwagę na akt oddania Duchowi Świętemu, ułożony przez Piusa X. Znamienne jest, że obok osobistego oddania się Trzeciej Osobie Trójcy Świętej, wyraźne wskazanie jest na jedność działania Ducha z nauczaniem Kościoła: „Duchu Święty, Duchu Boży, Duchu Światła i Miłości, Tobie poświęcam rozum mój, serce moje, wolę moją i całego siebie w życiu doczesnym i wiecznym. Spraw, aby mój rozum był zawsze chętny do przyjmowania natchnień pochodzących z nieba i nauki Kościoła Świętego, którym Ty nieomylnie kierujesz" ${ }^{11}$.

Kolejny papież Benedykt XV znany w sposób szczególny z reformy prawa kanonicznego, której owocem był tzw. kodeks pio-benedyktyński także zachował odwołania do działań Ducha Świętego. Encyklikę Maximum illud (1919), poświęcił działalności misyjnej Kościoła. Dostrzegł w niej działanie Ducha Świętego w charyzmacie misyjności. „Litując się nad tak opłakania godnym losem niezmiernej rzeszy dusz, nie mając nic ważniejszego w zakresie Świętego Naszego Urzędu Apostolskiego, jak dzielić się z nimi dobrodziejstwami Boskiego Odkupienia, zaiste z wielką radością i wdzięcznością widzimy, jak w świecie katolickim w wieloraki sposób wzmagają się wysiłki dobrych ludzi, podejmowane niewątpliwie pod tchnieniem Ducha Świętego w celu przyspieszenia rozwoju i rozkwitu misji zagranicznych" ${ }^{\prime 2}$.

Wskazując na cechy dobrego misjonarza, dostrzegł potrzebę kontemplacji zawierzenia Duchowi Świętemu: „[misjonarz] starać się będzie pociągać ich wszelkimi przejawami życzliwości chrześcijańskiej, aby kiedyś doprowadzić ich w objęcia Chrystusa - Dobrego Pasterza. W tej mierze często rozważać

\section{$10 \quad$ Tamże.}

11 Pius X, Poświęcenie sięDuchowi Świętemu, https://wduchuswietym.com/modlitwyducha/84modlitwy/124-poswiecenie-sie-duchowi-swietemu-sw-piusa-x [01.03.2021].

12 Benedykt XV, Maximum illud, http://rodzinakatolicka.pl/benedykt-xv-maximum-illud-o-misjach/ [01.03.2021]. 
będzie słowa Pisma Świętego: «O jak dobry i słodki jest, Panie, Duch Twój we wszystkim!»"13.

W zakończeniu encykliki Papież zauważył, że Kościół i jego działalność misyjna może istnieć dzięki działaniu Ducha Świętego. W innym przypadku wysiłki podejmowane przez misjonarzy byłyby z pewnością bezskuteczne ${ }^{14}$.

\section{„Nowa Pięćdziesiątnica”}

Spopularyzowane współcześnie rozumienie terminu „nowa Pięćdziesiątnica” sugeruje, jakoby tą nazwą określano powtórzenie wydarzeń z Wieczernika, nowe wylanie Ducha Świętego przejawiające się występowaniem niezwykłych zjawisk, zbliżone do tych, które znamy z opisu biblijnego ${ }^{15}$. Korzeni tego wydarzenia należy szukać u progu XX wieku pośród protestanckich wspólnot, które rzekomo, doświadczyły ponownego „Zesłania Ducha Świętego" ${ }^{16}$, dając początek odnowie charyzmatycznej, nazywanej także właśnie "nową Pięćdziesiątnicą”"17. Jednak czy właśnie takiej „nowej Pięćdziesiątnicy” mają być zwiastunami papieże Pius XI, Pius XII i Jan XXIII?

Dokumentem kluczowym do właściwego rozumienia „nowej Pięćdziesiątnicy" jest encyklika Ojca Świętego Piusa XI o tytule Mortalium animos (1928). W niej ów Papież podkreślił kilka, fundamentalnych dla rozpatrywanego zagadnienia, kwestii. Po pierwsze zaakcentował, że działanie Ducha Świętego w Kościele Chrystusowym, tj. katolickim, nigdy nie zatraciło ani swojej skuteczności ani też wartości ${ }^{18}$. Stąd też odnowa Kościoła ma następować nie przez czerpanie od tych, którzy odpadli od łączności z Kościołem Chrystusowym ${ }^{19}$, lecz wręcz przeciwnie - przez sprowadzanie ich do jedynej owczarni Zbawiciela ${ }^{20}$.

Papież Pius XII mówiąc o działaniu Ducha Świętego w Kościele, z całą stanowczością stwierdził w encyklice Mystici Corporis (1943), że Trzecia Osoba Trójcy Świętej jest życiową zasadą Kościoła ${ }^{21}$. Jasne jest więc to, że

\footnotetext{
13 Tamże.

14 Zob. tamże.

15 M. Hebrard, Charyzmatycy. Zarys historii Odnowy w Duchu Świętym, Kraków 1994.

16 Tamże.

17 Tamże.

18 Pius XI, Mortalium animos, https://opoka.org.pl/biblioteka/W/WP/pius_xi/encykliki/ mortalium_animos_06011928.html [01.03.2021].

19 Tamże.

20 Tamże.

21 J. Błaszczyszyn, Insegnamento pneumatologico di Giovanni Paolo II, „Kairós” Anno IV/1, Jan/Jun 2007, s. 50.
} 
Pięćdziesiątnica - Zesłanie Ducha nie jest obecnie czymś zewnętrznym w stosunku do Kościoła, lecz wydarzeniem z gruntu wewnętrznym, fundamentalnym dla życia kościelnego. Szczególne źródło tchnienia Ducha widział Ojciec Święty Pius XII w Piśmie Świętym i stąd też poświęcił jego egzegezie całą encyklikę Divino Afflante Spiritu (1943). Jednak w tejże encyklice wyznaczając kierunki egzegezie biblijnej podkreślił wartość egzegezy katolickiej²2, opartej na tradycji kościelnej i zakorzenionej w dziełach Ojców Kościoła. Papież zachęcił w niej do zgłębiania Pisma Świętego nie tylko kapłanów, ale i wiernych ${ }^{23}$.

Chronologicznie nam najbliższy, papież Jan XXIII, był pierwszym, który użył sformułowania „nowa Pięćdziesiątnica”. To sformułowanie ściśle łączył z Soborem Watykańskim II, już od samego początku mówiąc, że „planowane spotkanie Concilium oecumenicum powinno zgromadzić jakby na nowej Pięćdziesiątnicy [come a Pentecoste novella] przede wszystkim biskupów Kościoła" ${ }^{24}$. W podobnym tonie wypowiadał się jeszcze wiele razy mówiąc chociażby, że „Duchowni i świeccy, wszyscy pragną wspólpracować, aby Sobór przemienił się w jakby nową Pięćdziesiątnicę [come in una novella Pentecoste]” ${ }^{25}$ lub „Niewątpliwie zajaśnieje upragniona nowa Pięćdziesiątnica [la nuova desiderata Pentecoste], która obficie wzbogaci Kościół w duchowe energie"26. Nie poprzestawał jednak na życzeniach i deklaracjach, lecz również zachęcał do modlitwy w tej intencji: „Niech gorliwsza modlitwa do Boga popłynie z serc wszystkich - aby Jego Duch Święty - jak często to powtarzamy - odnowił w naszych czasach cuda jakby nowej Pięćdziesiątnicy [i prodigi come di una novella Pentecoste]” ${ }^{27}$ oraz „To jest nowa Pięćdziesiątnica [la novella Pentecoste], o którą gorliwie wołamy w Duchu Świętym jako o owoc Ekumenicznego Soboru Watykańskiego"28.

22 Pius XII, Divino AfflanteSpiritu, https://opoka.org.pl/biblioteka/W/WP/pius_xii/encykliki/ divino_afflante_30091943.html [01.03.2021].

23 Tamże.

24 Celebrazione dei Secondi Vespri nella Solennità di Pentecoste, Omelia del Santo Padre Giovanni XXIII, 17 maja 1959, http://www.vatican.va/content/john-xxiii/it/homilies/1959/ documents/hf_j-xxiii_hom_19590517.html [01.03.2021].

25 Giovanni XXIII, Il Tempio Massimo, 2 sierpnia 1962, http://www.vatican.va/content/ john-xxiii/it/letters/1962/documents/hf_j-xxiii_let_19620702_tempio-massimo.html [01.03.2021].

26 Discorso del Santo Padre Giovanni XXIII per la Chiusura del Primo Periodo del ss. Concilio, 8 grudnia 1962, http://www.vatican.va/content/john-xxiii/it/speeches/1962/documents/ hf_j-xxiii_spe_19621208_closing-i-period.html [01.03.2021].

27 Inaugurazione di un Nuovo Organo, Parole del Santo Padre Giovanni XXIII, 26 listopada 1962, http://www.vatican.va/content/john-xxiii/it/speeches/1962/documents/hf_j-xxiii_spe_19620926_inaugurazione-organo.html [01.03.2021].

28 Giovanni XXIII, Udienza generale, 24 października 1962, http://www.vatican.va/content/ john-xxiii/it/audiences/documents/hf_j-xxiii_aud_19621024.html [01.03.2021]. 
W świetle przytoczonych wcześniej stanowisk papieży wyłania się całkiem wyraźny obraz katolickiego rozumienia „nowej Pięćdziesiątnicy”. Przede wszystkim podkreślić należy, że owa „nowość” nie polega na odrębności fenomenu Zesłania jako wydarzenia historiozbawczego, lecz jest to ponowne odkrywanie, nowe zagłębianie się w to, co już się wydarzyło w Wieczerniku i cały czas trwa w Kościele aż do tej pory, bez żadnych przerw. W takim stanie rzeczy czymś sprzecznym z omówionym „papieskim zwiastowaniem” jest współczesna tendencja do bezkrytycznego niemal przeszczepiania obcych katolicyzmowi praktyk protestanckiego rodowodu. Co więcej, owe praktyki stają się pewnym niebezpieczeństwem zarówno dla katolickiej koncepcji eklezjologii oraz, wynikającej z niej, praktyki życia kościelnego. Oto bowiem tendencja do podkreślania „nowej Pięćdziesiątnicy” jako fenomenu nowego, odrębnego od dotychczasowego kontekstu, prowadzi do stwierdzenia, że, podobnie jak w przypadku rzeczywistej Pięćdziesiątnicy, która stała się fundamentem dla prawdziwego Kościoła Chrystusowego, fenomen ów stał się fundamentem dla nowego, ponaddenominacyjnego pseudo-Kościoła (warto podkreślić, że obecnie wspólnota zielonoświątkowa jest drugą, największą co do liczebności strukturą chrześcijańską), do którego wchodzi się przez nowy chrzest - chrzest w Duchu Świętym, a przekazanie nadzwyczajnych darów łaski - charyzmatów następuje przez nałożenie rąk szczególnie „obdarowanych duchowo” liderów (pseudohierarchia), a o skuteczności tego procederu mają świadczyć nadzwyczajne, widzialne znaki niewidzialnej laski (pseudosakramenty).

Tymczasem, dla katolików, jak mówi soborowa Konstytucja o liturgii w punkcie 7, źródłem i szczytem życia chrześcijańskiego nie są sentymentalne, zakrawające na mistykę, której natury do końca nie znamy, lecz liturgia i życie sakramentalne. W kontraście do tego stanowiska stoi rzeczywistość - współczesna praktyka życia kościelnego, gdzie liturgiczny kult Ducha Świętego uległ znacznemu zmniejszeniu. Chociażby w ciągu ostatnich lat XX wieku zlikwidowano uroczystą, liturgiczną wigilię Zesłania Ducha Świętego, liturgiczne akty rewerencji związane z Duchem Świętym jak np. postawa klęcząca (a więc błagalna) podczas liturgicznego wykonania Hymnu do Ducha Świętego (Veni Creator) czy też na wspomnienie oraz sam obchód liturgiczny Pięćdziesiątnicy - z 8 bowiem dni liturgicznego świętowania, uczyniono jeden dzień znosząc oktawę tego święta.

\section{Zakończenie}

Faktycznie przełom XIX i XX wieku można nazwać początkiem nowej ery Ducha Świętego. Poczynając od przełomowych encyklik Leona XIII, poświęconych Trzeciej Osobie Trójcy Świętej, w nauczaniu kolejnych papieży wątki 
pneumatologiczne są obecne, akcentowane i przytaczane w kontekście różnych dokumentów i tematów. Na potrzeby analizy tematu podjętego w tytule zostały wskazane jedynie niektóre aspekty i wątki dotyczące Ducha Świętego w nauczaniu papieży przełomu XIX i XX stulecia. Bez wątpienia od tamtego czasu mówienie o Osobie tego, który przez swoją łaskę pierwszy wzbudza naszą wiarę i udziela nowego życia , towarzyszy rzeczywistości eklezjalnej bardziej wyraziście niż wcześniej.

Podsumowując przyznać trzeba, że papieże Pius XI, Pius XII oraz Jan XXIII byli zwiastunami „nowej Pięćdziesiątnicy”, jednak przedmiot ich zapowiadania różni się od tego, jak współcześnie rozumiemy to pojęcie - „nowa Pięćdziesiątnica”. Przywołując nauczanie tych trzech papieży warto powrócić do „katolicyzacji” starań o ożywienie w Kościele podyktowane obecnością Ducha Świętego zgodnie z papieskimi wskazówkami oraz późniejszymi, Soborowymi kierunkami, których recepcja wciąż pozostawia wiele do życzenia.

Słowa kluczowe: Duch Święty, nowa Pięćdziesiątnica, nauczanie papieży.

\section{Bibliografia:}

1. Benedykt XV, Maximum Illud, http://rodzinakatolicka.pl/benedykt-xv-maximum-illud-o-misjach/ [01.03.2021].

2. Błaszczyszyn J, Insegnamento pneumatologico di Giovanni Paolo II, „Kairós” Anno IV/1, Jan/Jun 2007, s. 48-54.

3. Hebrard M., Charyzmatycy. Zarys historii Odnowy w Duchu Świętym, Kraków 1994.

4. Jan XXIII, Celebrazione dei Secondi Vespri nella Solennità di Pentecoste. Omelia del Santo Padre Giovanni XXIII, 17 maja 1959, http://www.vatican.va/content/john-xxiii/it/homilies/1959/documents/hf j-xxiii_hom_19590517.html [01.03.2021].

5. Jan XXIII, Discorso del Santo Padre Giovanni XXIII per la Chiusura del Primo Periodo del ss. Concilio, 8 grudnia 1962, http://www.vatican.va/content/john-xxiii/ it/speeches/1962/documents/hf_j-xxiii_spe_19621208_closing-i-period.html [01.03.2021].

6. Jan XXIII, Il Tempio Massimo, 2 sierpnia 1962, http://www.vatican.va/content/ john-xxiii/it/letters/1962/documents/hf_j-xxiii_let_19620702_tempio-massimo. html [01.03.2021].

7. Jan XXIII, Inaugurazione di un Nuovo Organo, Parole del Santo Padre Giovanni XXIII, 26 listopada 1962, http://www.vatican.va/content/john-xxiii/it/speeches/1962/ documents/hf_j-xxiii_spe_19620926_inaugurazione-organo.html [01.03.2021].

8. Jan XXIII, Udienza generale, 24 października 1962, http://www.vatican.va/content/ john-xxiii/it/audiences/documents/hf_j-xxiii_aud_19621024.html [01.03.2021].

9. Leon XIII, Divinum Illud, cyt. za: http://rodzinakatolicka.pl/leon-xiii-divinum-illud-o-duchu-swietym/ [01.03.2021].

10. Pius X, E Supremi Apostolatus, http://rodzinakatolicka.pl/sw-pius-x-e-supremiapostolatus-o-odnowieniu-wszystkiego-w-chrystusie/ [01.03.2021]. 
11. Pius X, Pascendi Dominici gergis, http://rodzinakatolicka.pl/sw-pius-x-pascendidominici-gregis-o-zasadach-modernistow/ [01.03.2021].

12. Pius XI, Mortalium animos, https://opoka.org.pl/biblioteka/W/WP/pius_xi/encykliki/mortalium_animos_06011928.html [01.03.2021].

13. Pius XII, Divino Afflante Spiritu, https://opoka.org.pl/biblioteka/W/WP/pius_xii/ encykliki/divino_afflante_30091943.html [01.03.2021].

14. Szostakiewicz S., Duch Święty a duch naszych czasów, https://opoka.org.pl/biblioteka/T/TS/czasy.html [01.03.2021]. 